\title{
Ketimpangan, Pola Spasial, dan Kinerja Pembangunan Wilayah di Provinsi Jawa Timur
}

\author{
Disparity, Spatial Pattern, and Performance of Regional Development \\ in East Java Province
}

\begin{abstract}
Mohammad Reza Fauzi ${ }^{1 *}$, Ernan Rustiadi ${ }^{2}$ \& Sri Mulatsih ${ }^{3}$
${ }^{1}$ Magister Ilmu Perencanaan Pembangunan Wilayah dan Perdesaan, Sekolah Pascasarjana, Institut Pertanian Bogor, Kampus IPB Dramaga, Bogor 16680, Indonesia; ${ }^{2}$ Departemen Ilmu Tanah dan Sumberdaya Lahan, Fakultas Pertanian, Institut Pertanian Bogor, Kampus IPB Dramaga, Bogor 16680, Indonesia; ${ }^{3}$ Departemen Ilmu Ekonomi, Fakultas Ekonomi dan Manajemen, Institut Pertanian Bogor, Kampus IPB Dramaga, Bogor 16680, Indonesia; *Penulis korespondensi. e-mail: fauzi.eza@gmail.com
\end{abstract}

(Diterima: 1 Agustus 2019; Disetujui: 13 Desember 2019)

\begin{abstract}
Development is a multidimensional process that aims to generate significant changes in the betterment of people's lives. However, development does not always able to form regional balance. The phenomenon of disparity always shades the regional development process. As a province with the highest number of regencies and cities, the development of East Java Province is inseparable from the phenomenon of disparity. This study aimed to analyze the performance, regional disparities, and spatial autocorrelation of regional development in East Java Province in 2017. Performance of regional development was measured using TOPSIS analysis. Level of regional disparity was calculated by the Coefficient Variation (CV). Spatial pattern of development performance was explored through analysis of spatial autocorrelation by Moran Index and Local Indicator of Spatial Autocorrelation (LISA). Results of analysis on regional development performance show that Kediri City had the highest performance in East Java Province, meanwhile Tuban Regency had the lowest performance. At the regional level, Pantura (North Coast) and Central Region have higher regional development performance average compared to Pansela (South Coast), Tapal Kuda, and Madura regions. Regional disparity in East Java Province occur between regions and within regions (between regencies/cities). Pantura is the region with the highest regional development performance disparity, meanwhile Madura region is relatively homogenous with low development performance. Result of Moran and LISA analysis interpret that spatial and contiguity aspects effect regional development significantly which tends to form a cluster pattern. Therefore, spatial factors and regional linkage are essential elements in regional development.
\end{abstract}

Keywords: LISA, Moran Index, regional development, regional disparities, TOPSIS.

\begin{abstract}
ABSTRAK
Pembangunan merupakan proses multidimensi yang bertujuan menciptakan perubahan mendasar bagi kehidupan masyarakat ke arah yang lebih baik. Akan tetapi, pembangunan tidak selalu menghasilkan pemerataan bagi setiap wilayah. Ketimpangan merupakan sebuah fenomena yang akan selalu membayangi proses pembangunan wilayah. Sebagai provinsi dengan jumlah kabupaten/kota terbanyak di Indonesia, pembangunan wilayah Provinsi Jawa Timur tidak terlepas
\end{abstract}


dari fenomena ketimpangan. Penelitian ini bertujuan untuk menganalisis kinerja, ketimpangan, dan pola spasial pembangunan wilayah di Provinsi Jawa Timur pada tahun 2017. Kinerja pembangunan wilayah dianalisis menggunakan TOPSIS berdasarkan dimensi sosial ekonomi, pendidikan dan kesehatan masyarakat, serta aksesibilitas wilayah. Analisis ketimpangan pembangunan wilayah menggunakan perhitungan koefisien variasi $(\mathrm{CV})$ dari nilai kinerja pembangunan wilayah. Pola spasial kinerja pembangunan wilayah diketahui melalui analisis autokorelasi spasial dengan Indeks Moran dan Local Indicator of Spatial Autocorrelation (LISA). Hasil analisis kinerja pembangunan wilayah menunjukkan Kota Kediri merupakan wilayah berkinerja tertinggi di Provinsi Jawa Timur. Pada lingkup perwilayahan, Wilayah Pantura dan Tengah memiliki rata-rata kinerja pembangunan yang lebih tinggi daripada wilayah Pansela, Tapal Kuda, dan Madura. Ketimpangan wilayah di Provinsi Jawa Timur terjadi baik antarwilayah maupun di dalam wilayah. Ketimpangan wilayah tertinggi berada di Wilayah Pantura, sedangkan Wilayah Madura memiliki homogenitas (ketimpangan rendah) dengan kinerja pembangunan yang relatif rendah. Analisis Moran dan LISA menyatakan kinerja pembangunan wilayah di Jawa Timur memiliki autokorelasi spasial signifikan dengan kecenderungan pola berklaster. Dengan demikian, faktor spasial dan keterkaitan wilayah menjadi unsur penting dalam pembangunan wilayah.

Kata kunci: Indeks Moran, ketimpangan wilayah, LISA, pembangunan wilayah, TOPSIS.

\section{PENDAHULUAN}

Provinsi Jawa Timur terletak di lokasi yang staregis, menjadi gerbang penghubung antara kawasan ekonomi Indonesia Bagian Barat dengan kawasan ekonomi Indonesia Bagian Tengah dan Timur. Faktor lokasi tersebut merupakan salah satu alasan Jawa Timur memegang peranan dalam perekonomian nasional. Sebagai provinsi dengan jumlah kabupaten/kota terbanyak (29 kabupaten dan 9 kota), Jawa Timur merupakan provinsi dengan kekuatan ekonomi terbesar kedua setelah DKI Jakarta dengan produk domestik regional bruto (PDRB) atas dasar harga konstan (ADHK) Tahun 2017 sebesar Rp2,019.2 triliyun dengan sumbangsih terhadap pangsa nasional senilai 14.86\%. Sedangkan PDRB perkapita Provinsi Jawa Timur tahun 2017 mencapai Rp37.72 juta (BPS Jatim, 2018). Lumbatoruan dan Hidayat (2013) menyatakan terdapat keseimbangan jangka panjang dan arah pergerakan yang sama antara pertumbuhan ekonomi dan pembangunan manusia. Hubungan PDRB perkapita dan indeks pembangunan manusia (IPM) memiliki keterkaitan dua arah (two-way relationship) yang positif. PDRB perkapita yang tinggi akan menghasilkan peningkatan IPM, begitu pula capaian IPM yang tinggi akan meningkatkan PDRB perkapita (Ezkirianto, 2013).

IPM Provinsi Jawa Timur pada tahun 2017 sebesar 70.27, nilai tersebut merupakan nilai terendah jika dibandingkan dengan provinsi lain di Pulau Jawa, bahkan lebih rendah dari nilai IPM Indonesia yang senilai 70.81 (BPS Jatim, 2018). Uraian diatas menyatakan bahwa Provinsi Jawa Timur memiliki capaian PDRB perkapita tinggi, tetapi capaian IPM sangat rendah. Kondisi tersebut merupakan salah satu indikasi terjadinya ketimpangan (Ezkirianto, 2013). Pencapaian PDRB perkapita dan IPM yang tidak sejalan dapat mencerminkan aktivitas pembangunan masih berfokus pada aspek ekonomi, tetapi pembangunan dimensi kesehatan, pendidikan, dan standar hidup layak masyarakat masih terabaikan.

Pada lingkup wilayah geografis, kabupaten/kota di Provinsi Jawa Timur dapat diklasifikasikan menjadi Wilayah Pantura (Pantai Utara), Tengah, Pansela (Pantai Selatan), Tapal Kuda dan Pulau Madura, seperti pada peta di Gambar 1. Wilayah Pantura terdiri dari 7 kabupaten/kota yang berada di pantai utara, mulai dari Kabupaten Tuban hingga Kabupaten Pasuruan. Wilayah Pansela terdiri dari 5 kabupaten/kota yang berada di pantai 
selatan, mulai dari Kabupaten Pacitan hingga Kabupaten Malang. Wilayah Tengah terdiri dari 15 kabupaten/kota, terletak di tengah daratan dan tidak memiliki pantai, Wilayah Tapal Kuda terdiri dari 6 Kabupaten dan 1 Kota mulai dari
Kabupaten Probolinggo dan Lumajang hingga Kabupaten Banyuwangi; sedangkan Wilayah Pulau Madura terdiri dari 4 kabupaten, yakni Kabupaten Bangkalan, Sampang, Pamekasan dan Sumenep.

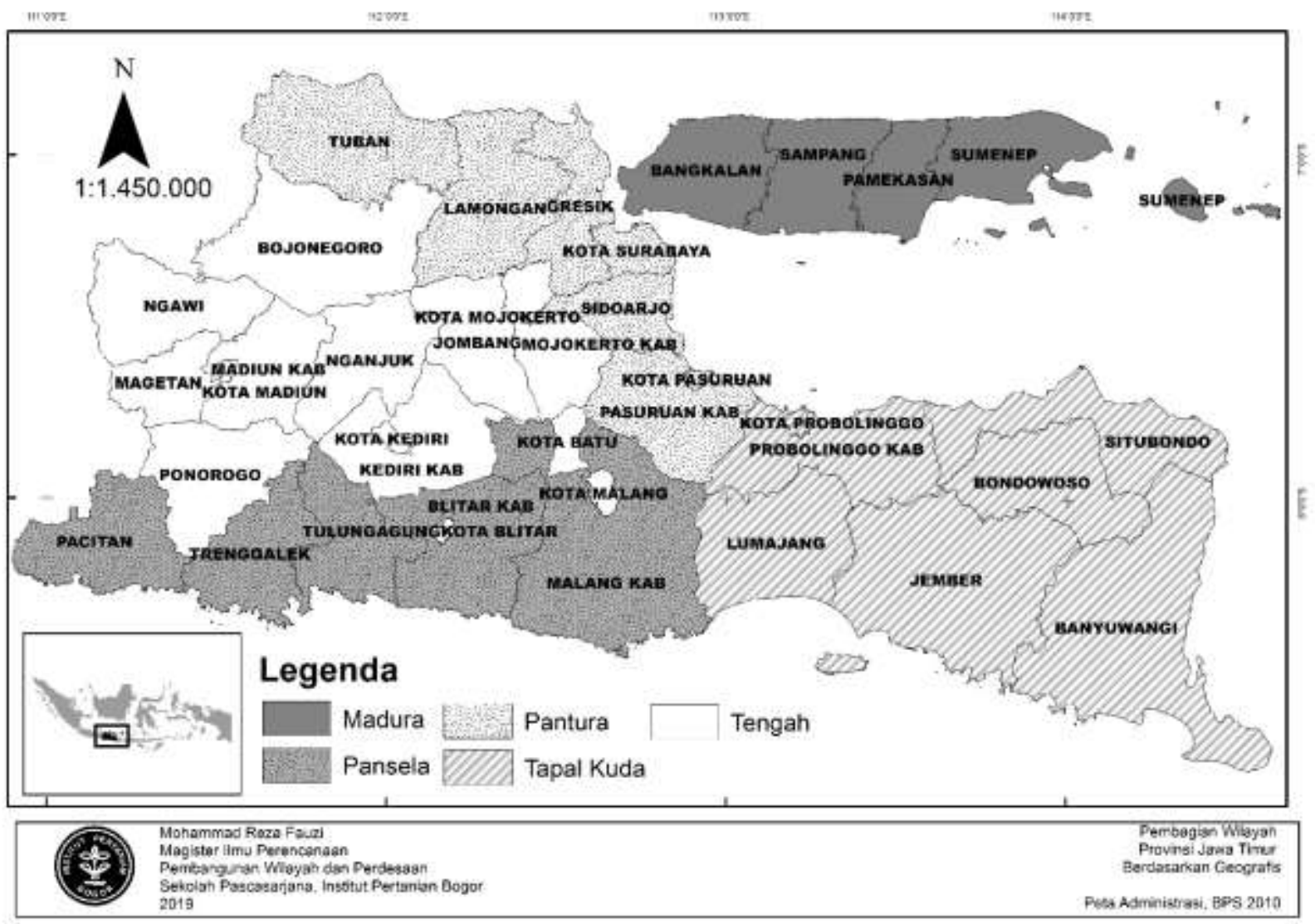

Gambar 1. Peta wilayah Provinsi Jawa Timur berdasarkan kondisi geografis

Ketimpangan wilayah yang terjadi diantara kabupaten/kota di Provinsi Jawa Timur telah disadari oleh pemerintah dan menjadi isu strategis dalam permasalahan pembangunan daerah sebagaimana yang telah tertuang dalam RPJMD (Rencana Pembangunan Jangka Menengah Daerah) Provinsi Jawa Timur tahun 2014-2019. Ketimpangan yang diukur melalui perbedaan PDRB perkapita antara Wilayah Pantura (Kota Surabaya, Kabupaten Gresik, Kabupaten Sidoarjo) dan Tengah (Kota Kediri dan Kota Malang) yang terkategori tinggi dengan Wilayah Pansela (Kabupaten Pacitan, Trenggalek, dan Ponorogo), Tapal Kuda (Kabupaten Bondowoso dan Jember) dan Pulau Madura. Hal ini telah dikaji sebelumnya dan menjadi perhatian serius yang harus ditanggulangi dalam kebijakan pembangunan Pemerintah Provinsi Jawa Timur, sebagaimana yang tercantum dalam RPJMD.

Tabel 1 menjelaskan secara umum capaian PDRB per kapita dan IPM Wilayah di Provinsi Jawa Timur pada tahun 2017. Wilayah Pantura dan Tengah memiliki capaian yang lebih tinggi jika dibandingkan dengan lainnya. Rata-rata PDRB per kapita Wilayah Pansela, Tapal Kuda dan Madura jauh lebih rendah dibandingkan rata-rata PDRB perkapita Provinsi Jawa Timur sebesar Rp37.72 juta, dengan gap sekitar Rp18.07 juta. Fakta tersebut menyatakan 16 kabupaten/kota yang berada Wilayah Pansela dan Pulau Madura memiliki tingkat kemakmuran wilayah relatif tertinggal. 
Tabel 1 Perbandingan PDRB per kapita dan IPM Tahun 2017 berdasarkan wilayah

\begin{tabular}{lllllll}
\hline & Pantura & Tengah & Pansela & Tapal Kuda & Madura & Jatim \\
\hline Mean PDRB perkapita (Rp.Juta) & 56.68 & 48.50 & 20.49 & 22.18 & 16.27 & 37.72 \\
Geomean IPM (Indeks) & 73.19 & 73.17 & 68.71 & 66.46 & 62.82 & 70.27 \\
\hline Sum
\end{tabular}

Sumber: BPS Jatim (2018)

Capaian IPM tahun 2017 juga memiliki pola yang sama dimana Wilayah Pantura dan Tengah memiliki nilai rata-rata (geomean) yang lebih tinggi daripada Wilayah Pansela, Tapal Kuda dan Pulau Madura. Uraian tersebut menunjukan bahwa tidak terjadi perubahan pola ketimpangan antara kinerja pembangunan ekonomi dan manusia di tahun 2017 setelah 3 tahun RPJMD Provinsi Jawa Timur telah dilaksanakan, sehingga pengukuran kinerja pembangunan diperlukan.

Kinerja merupakan hasil atau tingkat keberhasilan yang terukur. Dalam upaya mengukur kinerja pembangunan, dibutuhkan perspektif yang lebih luas untuk memahami makna pembangunan wilayah seutuhnya. Pembangunan memiliki konsep multidimensi dan dipahami dalam perspektif lokal (Cobbinah \& Black, 2011). Kinerja pembangunan dapat diukur melalui pertumbuhan ekonomi, pengurangan ketimpangan, dan penanggulangan kemiskinan (Todaro \& Smith, 2011). Pada aspek pembangunan manusia (people centered development), kinerja diketahui melalui akses dan kualitas pelayanan pendidikan dan kesehatan, serta kehidupan masyarakat yang berkualitas (UNDP, 1990).

Pada perspektif wilayah, pembangunan memiliki perthatian pada aspek keterkaitan (linkages) antarwilayah (Mahi, 2016). Aksesibilitas wilayah mengindikasikan keterkaitan wilayah dalam hal keterjangkauan fisik wilayah. Aksesibilitas wilayah berkaitan dengan kemampuan mengakses tempat dan memberikan manfaat sosial ekonomi dasar bagi individu dalam mobilisasi, berinteraksi, dan aliran barang sehingga dapat meningkatkan daya, inovasi dan kinerja perekonomian wilayah (Salonen, 2014). Maka aksesibilitas wilayah menjadi faktor penting dalam pembangunan. Selain memasukkan aksesibilitas wilayah dalam dimensi pengukuran kinerja pembangunan, diperlukan juga pengujian seberapa besar pengaruh faktor spasial dan keterkaitan dalam kinerja pembangunan wilayah.

Terdapat beberapa kajian yang menganalisis kinerja pembangunan wilayah berdasarkan multidimensi dan ketimpangannya. Krimi et al. (2010) melakukan kajian mengenai kesenjangan dan pembangunan wilayah menggunakan dimensi sosial ekonomi, budaya, pendidikan dan kesehatan. Dai \& Zhang (2011) juga melakukan kajian serupa di Provinsi Zhejiang, China. Dimensi yang digunakan dalam kajian ini adalah skala ekonomi, struktur industri, kondisi hidup masyarakat, dan perdagangan internasional.

Kajian keterkaitan spasial dalam indikator pembangunan wilayah telah banyak dipublikasi, seperti: Panjaitan (2012) dengan variabel IPM, Putra (2017) dengan variabel PDRB, Pratiwi dan Kuncoro (2016) dengan variabel PDRB perkapita, dan Harmes et al. (2017) dengan variabel kemiskinan menyatakan bahwa masing-masing variabel tersebut memiliki keterkaitan spasial yang signifikan dengan kecenderungan pola berklaster. Hasil ini menyatakan bahwa variabel tersebut dipengaruhi oleh faktor keterkaitan spasial.

$$
\text { Berdasarkan kondisi, kasus }
$$
pembangunan di Provinsi Jawa Timur, dan tinjauan literatur di atas, maka kajian mengenai kinerja pembangunan wilayah dan ketimpangannya dalam dimensi sosial ekonomi, akses dan kualitas pendidikan dan kesehatan masyarakat, serta aksesibilitas wilayah menjadi menarik dan penting dilakukan. Kajian ini memiliki tujuan untuk (1) menganalisis kinerja pembangunan wilayah menurut kabupaten/kota dan wilayah geografis Provinsi Jawa Timur dan mengukur ketimpangan wilayah; dan (2) mengidentifikasi keterkaitan (autokorelasi spasial) dan pola spasial kinerja pembangunan wilayah. 


\section{METODOLOGI}

Penelitian menggunakan unit analisis 38 kabupaten/kota di Provinsi Jawa Timur. Data yang digunakan dalam penelitian ini merupakan data sekunder pada tahun 2017 yang diperoleh dari BPS, Dinas Penanaman Modal, Dinas Pendidikan, Dinas Kesehatan, Bina Marga Provinsi Jawa Timur; dan Direktorat Jenderal Bina Marga Kementerian Pekerjaan Umum dan Perumahan Rakyat, Google Maps, publikasi dan literatur terkait.

\section{Analisis Kinerja Pembangunan Wilayah}

Pada analisis kinerja pembangunan wilayah, digunakan metode analisis TOPSIS. TOPSIS (Technique for Order Preference by
Similarity to Ideal Solution) dikembangkan oleh Hwang dan Yoon pada tahun 1981. TOPSIS dirancang berdasarkan konsep solusi alternatif terbaik yang dekat dengan solusi ideal positif (solusi optimal) dan yang jauh dari solusi ideal negatif (solusi buruk) (Tzeng \& Huang, 2011). Kemudian, memilih alternatif terbaik melalui penyortiran. Solusi yang disepakati berdasarkan jarak euclidean terdekat dari solusi ideal positif dan jarak euclidean terjauh dari solusi buruk negatif. Indikator yang digunakan untuk mengukur capaian pembangunan wilayah masing-masing kabupaten/kota sebanyak delapan belas dapat dilihat pada Tabel 2 .

Tabel 2. Dimensi dan indikator penelitian

\begin{tabular}{ll}
\hline Dimensi & Indikator \\
\hline & PDRB per kapita (Rp.Juta) \\
& Kontribusi PDRB Industri Manufaktur (\%) \\
Sosial Ekonomi & Penanaman modal dalam negeri (Rp.Triliun) \\
& Penanaman modal asing (Rp.Triliun) \\
& Persen pengangguran \\
& Persen kemiskinan \\
& Jumlah kasus kriminal (tindak pidana) \\
& Persen penduduk dengan keluhan kesehatan mengganggu \\
& Jumlah bayi bergizi buruk \\
& Rasio tempat tidur rumah sakit per 1000 penduduk \\
& Persen rumah sehat \\
\hline \multirow{3}{*}{ Kesehatan } & Rasio guru-murid \\
& Rata-rata lama sekolah \\
& Penduduk $\geq 15$ th lulusan pendidikan tinggi \\
& Angka partisipasi sekolah \\
\hline \multirow{3}{*}{ Pendidikan } & Indeks konektivitas gamma ${ }^{1}$ \\
& Rasio panjang jalan per luas wilayah $\left(\mathrm{km} / \mathrm{km}^{2}\right)^{2}$ \\
& Waktu tempuh perjalanan antar wilayah ${ }^{3}(\mathrm{menit})$ \\
\hline
\end{tabular}

\footnotetext{
1 Indeks konektivitas gama merupakan indikator yang digunakan untuk mengukur kualitas jaringan jalan dalam menjangkau suatu wilayah dengan memperbandingkan simpul dan ruas jalan dalam sebuah jaringan (Kansky \& Danscoine, 1989).

2 Rasio panjang jalan terhadap luas wilayah yang mencerminkan tingkat pelayan dan ketersediaan jaringan jalan dibandingkan dengan luas wilayah yang harus dilayani (Brotodewo, 2010; Indrashanty \& Legowo, 2016).

${ }^{3}$ Waktu tempuh perjalanan antarwilayah diperoleh menggunakan matriks asal tujuan dengan unit ukur waktu perjalan (Sulistyono et al., 2018).
} 
Data masing-masing kabupaten/kota dan indikator disusun ke dalam matriks TOPSIS. Setelah matriks tersusun, dilakukan normalisasi matriks dengan rumus sebagai berikut:

$$
\overline{X_{i j}}=\frac{X_{i j}}{\sqrt{\sum_{j=1}^{n} X_{i j}^{2}}}
$$

dimana, $X_{i j}$ adalah data/nilai indikator pembangunan wilayah $\mathrm{j}$ pada kabupaten/kota i.

Kemudian, matriks normalisasi terbobot dihitung dengan rumus di bawah ini:

$$
V_{i j}=\overline{X_{i j}} \cdot W_{j}
$$

dimana, $\mathrm{W}_{\mathrm{j}}$ adalah bobot indikator pembangunan wilayah $\mathrm{j}$.

Setelah itu, dihitung nilai solusi ideal positif (SIP) dan solusi ideal negatif (SIN).

$$
\begin{aligned}
& S I P=V^{+}=\left\{V_{1}^{+}, V_{2}^{+}, \ldots \ldots, V_{n}^{+}\right\} \\
& =\left\{\left(\max V_{i j} \mid i \in j_{1}\right),\left(\min V_{i j} \mid i \in j_{2}\right)\right\} \\
& \operatorname{SIN}=V^{-}=\left\{V_{1}^{-}, V_{2}^{-}, \ldots \ldots, V_{n}^{-}\right\} \\
& =\left\{\left(\min V_{i j} \mid i \in j_{1}\right),\left(\max V_{i j} \mid i \in j_{2}\right)\right\}
\end{aligned}
$$

Langkah selanjutnya adalah menghitung pemisah antara SIP dan SIN dengan mengukur jarak euclidean SIP $\left(\mathrm{S}_{\mathrm{i}}^{+}\right)$dan jarak euclidean $\operatorname{SIN}\left(\mathrm{S}_{\mathrm{i}}^{-}\right)$.

$$
\begin{aligned}
& S_{i}^{+}=\sqrt{\sum_{j=1}^{n}\left(V_{i j}-V_{j}^{+}\right)^{2}, i}=1,2, \ldots m \\
& S_{i}^{-}=\sqrt{\sum_{j=1}^{n}\left(V_{i j}-V_{j}^{-}\right)^{2}, i}=1,2, \ldots m
\end{aligned}
$$

Setelah didapatkan nilai jarak euclidean, kemudian dihitung kedekatan relatif/preferensi terhadap solusi ideal, melalui rumus sebagai berikut:

$$
P_{i}=\frac{S_{i}^{-}}{S_{i}^{+}+S_{i}^{-}}, i=1,2, \ldots, m
$$

dimana $0 \leq \mathrm{P}_{\mathrm{i}} \leq 1$, alternatif i mendekati nilai ideal positif atau mendekati 1 .

Nilai Pi merupakan kinerja pembangunan wilayah kabupaten/kota. Langkah selanjutnya adalah dilakukan pengkategorian status kinerja pembangunan wilayah kemudian dipetakan. Status kinerja dikategorikan dengan ketentuan selang Pi, sebagai berikut:

Tabel 3. Pengkategorian status berdasarkan selang

\begin{tabular}{ll}
\hline Selang & Status Kinerja \\
\hline$P_{i}>\left(\bar{P}_{+}\left(1 / 2 \mathrm{~S}_{\mathrm{P}}\right)\right)$ & Tinggi \\
$\left(\bar{P}_{-}\left(1 / 2 \mathrm{~S}_{\mathrm{P}}\right)\right) \leq P_{i} \leq\left(\bar{P}_{+}\left(1 / 2 \mathrm{~S}_{\mathrm{P}}\right)\right)$ & Sedang \\
$P_{i} \leq\left(\bar{P}_{-}\left(1 / 2 \mathrm{~S}_{\mathrm{P}}\right)\right)$ & Rendah \\
\hline
\end{tabular}

dimana, $\overline{\boldsymbol{P}}$ : rataan kinerja pembangunan di wilayah i dan $\mathrm{S}_{\mathrm{P}}$ : standar deviasi kinerja pembangunan

Pada analisis tingkat ketimpangan wilayahnya, dilakukan perhitungan koefisien variasi (CV) kinerja pembangunan wilayah. Koefisien variasi digunakan untuk melihat keragaman kinerja pembangunan dalam kelompok wilayah Pantura, Tengah, Pansela, Tapal Kuda dan Madura. Semakin besar nilai $\mathrm{CV}$, semakin besar keragaman antaranggota wilayahnya. $\mathrm{CV}$ dihitung dengan membandingkan tingkat standar deviasi capaian pembangunan wilayah dengan rata-rata nilai capaian pembangunan wilayah.

$$
C V_{W i l}=\frac{S_{C_{W i l}}}{\overline{P_{W u l}}}
$$

dimana, $C V_{W i l}$ merupakan koefisien variasi kelompok wilayah, $S_{C \text { Wil }}$ merupakan standar deviasi kinerja pembangunan wilayah, $P_{W i l}$ merupakan nilai rataan kinerja pembangunan wilayah. 


\section{Analisis Pola Spasial}

\section{Kinerja Pembangunan Wilayah}

Analisis keterkaitan spasial kinerja pembangunan wilayah di Provinsi Jawa Timur dilakukan Uji Moran Global (I). Uji moran bertujuan untuk mengidentifikasi autokolerasi spasial yang ditimbulkan adanya interaksi antarwilayah. Adapun rumus untuk menghitung autokorelasi spasial dengan menggunakan Indeks Moran (Lee \& Wong, 2001), sebagai berikut:

$$
I=\frac{n \sum_{i=1}^{n} \sum_{j=1}^{n} w_{i j}\left(x_{i}-\bar{x}\right)\left(x_{j}-\bar{x}\right)}{\sum_{i=1}^{n}\left(x_{i}-\bar{x}\right)^{2}}
$$

dimana, I adalah indeks moran, $x_{i}$ adalah kinerja pembangunan wilayah pada lokasi kabupaten/kota i, $x_{j}$ adalah nilai kinerja pembangunan wilayah pada lokasi kabupaten/kota $\mathrm{j}, \bar{x}$ adalah nilai rataan kinerja pembangunan wilayah, dan $w_{i j}$ adalah bobot terstandarisasi antara kabupaten/kota i dan j.

Autokorelasi spasial merupakan korelasi yang terjadi dan diamati pada data spasial dan lokasi dalam bidang dua dimensi. Data yang diamati dan faktor lokasional merupakan kesatuan dalam lanskap geografis. Faktor lokasional dalam autokorelasi spasial umumnya diartikan sebagai kedekatan geografis. Konsep ini sebagaimana hukum geografi pertama Tobler yang menyatakan, "segala sesuatu saling terkait dengan yang lainnya, akan tetapi sesuatu yang berdekatan lebih saling terkait, dibandingkan dengan yang berjauhan. Autokorelasi spasial dapat diintepretasikan sebagai tingkat relasi antarnilai pengamatan dan pola spasial (Griffith \& Chun, 2013). Berikut merupakan kriteria hipotesis dalam uji moran:
$\mathrm{H}_{0}: \mathrm{I}=0$ (tidak ada autokorelasi antarwilayah)

$\mathrm{H}_{1}: \mathrm{I} \neq 0$ (ada autokorelasi antarwilayah)

Pada tingkat lokal (kabupaten), digunakan Uji Local Indicator of Spatial Autocorrelation (LISA). Kemudian output uji LISA diklasifikasikan ke dalam empat hubungan spasial (Zhukov 2010 dalam Dhiyaa'ulhaq, 2017), yakni:

1. Kuadran HH (High-High), mengidentifikasi wilayah dengan nilai pengamatan tinggi dikelilingi oleh wilayah yang mempunyai nilai pengamatan tinggi.

2. Kuadran LH (Low-High), mengidentifikasi wilayah dengan nilai pengamatan rendah dikelilingi oleh wilayah yang mempunyai nilai pengamatan tinggi.

3. Kuadran LL (Low-Low), mengidentifikasi wilayah dengan nilai pengamatan rendah dikelilingi oleh wilayah yang mempunyai nilai pengamatan rendah.

4. Kuadran HL (High-Low), mengidentifikasi wilayah dengan nilai pengamatan tinggi dikelilingi oleh wilayah yang mempunyai nilai pengamatan rendah.

\section{HASIL DAN PEMBAHASAN}

Provinsi Jawa Timur merupakan provinsi besar yang terdiri dari 29 kabupaten dan 9 kota, dengan Kota Surabaya sebagai Ibukota Provinsi. Provinsi Jawa Timur memiliki luas wilayah sebesar 48,039.14 $\mathrm{km}^{2}$; dan berpenduduk tertinggi kedua dengan populasi sebanyak 39.293 juta jiwa. Di sisi lain, Provinsi Jawa Timur juga merupakan wilayah dengan jumlah penduduk miskin yang berada pada peringkat pertama secara nasional, sebesar 4.41 juta jiwa. 
Journal of Regional and Rural Development Planning (Jurnal Perencanaan Pembangunan Wilayah dan Perdesaan) Oktober 2019, 3 (3): 157-171

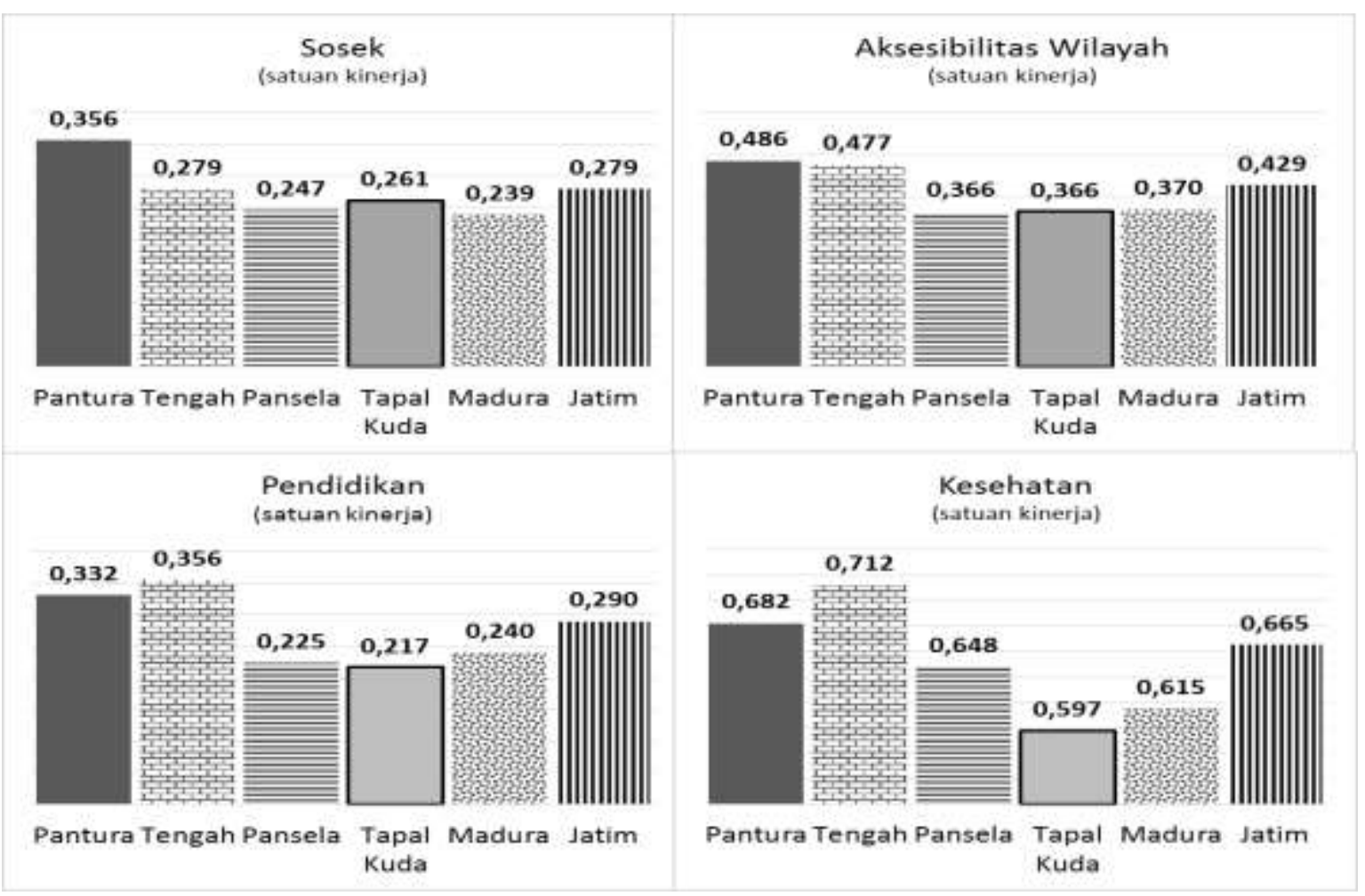

Gambar 2. Perbandingan geomean kinerja pembangunan wilayah berdasarkan dimensi dan wilayah geografis Sumber: Data diolah

\section{Kinerja Pembangunan Wilayah}

Hasil analisis kinerja pembangunan wilayah merupakan output dari analisis TOPSIS yang menggunakan dimensi sosial ekonomi, kesehatan masyarakat, pendidikan masyarakat, dan aksesibilitas wilayah. Hasil pembobotan indikator oleh para ahli pada 18 indikator menyatakan bahwa dimensi sosial ekonomi merupakan dimensi dengan rata-rata bobot tertinggi, sedangkan indikator dengan penilaian bobot tertinggi adalah PDRB per kapita, persen kemiskinan, dan persen pengangguran.

Hasil pengukuran rata-rata geometris (geomean) kinerja pembangunan wilayah berdasarkan dimensi dan wilayah geografis disajikan pada Gambar 2. Pada dimensi sosial ekonomi (sosek), Wilayah Pantura (0.356) merupakan satu-satunya wilayah dengan capaian rata-rata kinerja sosek lebih tinggi dari rata-rata kinerja sosek Jawa Timur (0.279). Kabupaten Pasuruan (0.560) merupakan wilayah dengan kinerja sosek tertinggi di Wilayah Pantura. Sedangkan Wilayah Madura merupakan wilayah memiliki kinerja sosek terendah (0.239), dengan Kabupaten Bangkalan sebagai wilayah berkinerja paling rendah (0.231).

Kinerja pembangunan pada dimensi pendidikan menunjukan bahwa Wilayah Pantura dan Tengah capaian memiliki akses dan kualitas pendidikan masyarakat yang lebih baik dari wilayah lainnya. Wilayah Tengah merupakan pencapai kinerja pendidikan tertinggi (0.356) dengan Kota Madiun sebagai pemilik kinerja paling tinggi (0.792). Di lain pihak, Wilayah Tapal Kuda merupakan wilayah berkinerja pendidikan terendah (0.597), dengan Kabupaten Banyuwangi yang berada di posisi paling rendah (0.143). Pada dimensi kesehatan, Wilayah Tengah memiliki rata-rata kinerja kesehatan tertinggi (0.712), dengan pencapaian tertinggi diperoleh Kota Madiun (0.962). Sedangkan Wilayah Tapal Kuda merupakan wilayah dengan kinerja kesehatan terendah (0.597), dengan posisi paling rendah berada pada Kabupaten Banyuwangi (0.493). Kinerja dimensi aksesibilitas wilayah menunjukan bahwa Wilayah Pantura dan Tengah memiliki ketersediaan dan kualitas infrastruktur yang lebih baik dari wilayah lainnya sehingga menghasilkan aksesibilitas yang lebih tinggi. 
Wilayah Pantura memiliki rata-rata kinerja aksesibilitas wilayah tertinggi (0.486), dengan posisi tertinggi ditempati Kota Pasuruan (0.974). Di sisi lain, Wilayah Pantura dan Tapal Kuda merupakan wilayah berkinerja aksesibilitas wilayah terendah (0.366), dengan Kabupaten Banyuwangi berada pada posisi paling rendah (0.256).

Hasil analisis kinerja pembangunan wilayah secara keseluruhan kemudian dilakukan perhitungan selang nilai umtuk menentukan kriteria status pembangunan wilayah dengan menggunakan rumus yang terdapat pada Tabel 3, sehingga dihasilkan kriteria sebagai berikut:

a. Kinerja Rendah, merupakan kinerja yang memiliki nilai kurang dari 0.295 .

b. Kinerja Sedang, merupakan kinerja yang memiliki nilai diantara 0.295-0.377.

c. Kinerja Tinggi, merupakan kinerja yang memiliki nilai lebih dari 0.377 .

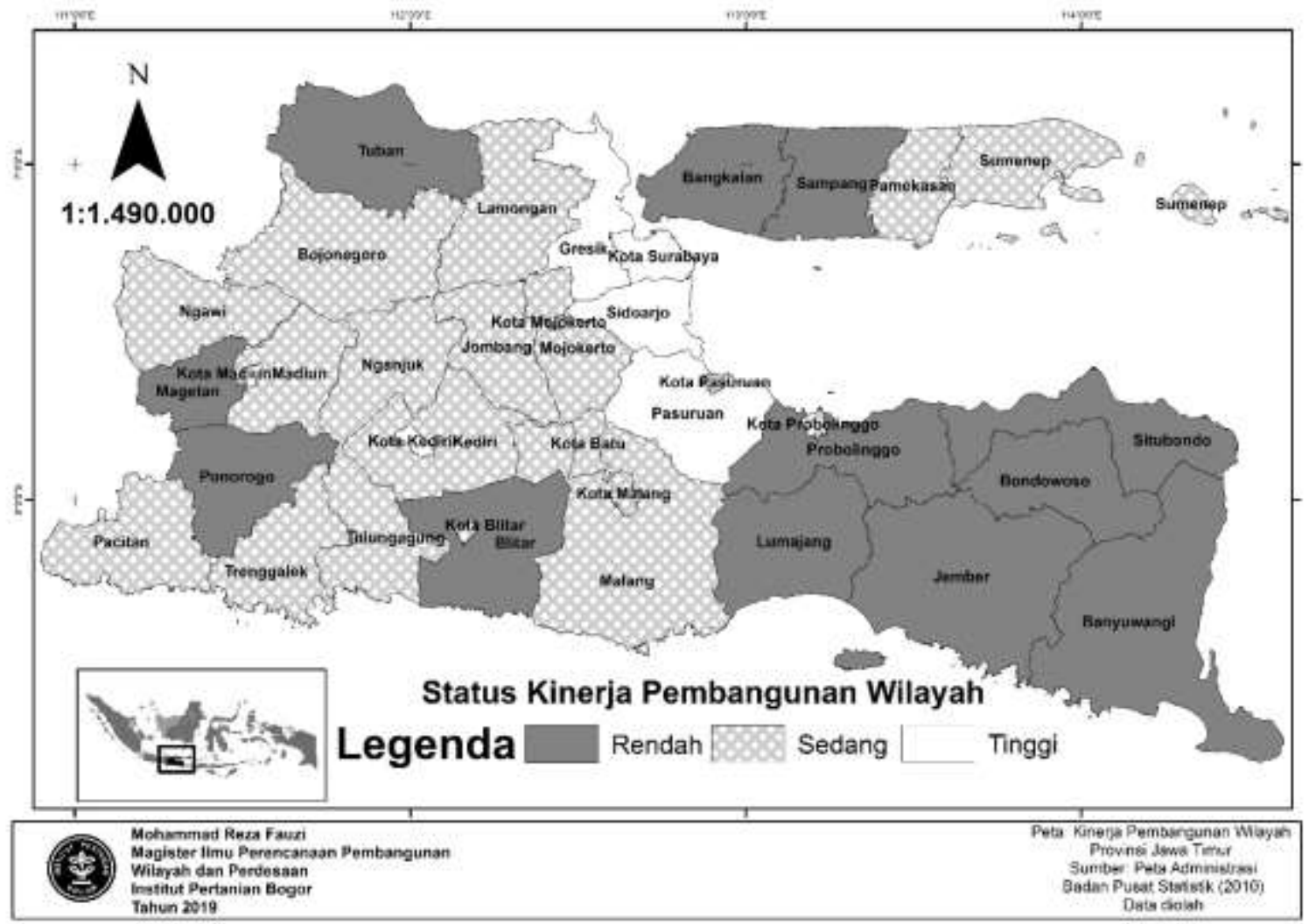

Gambar 3. Peta kinerja pembangunan wilayah Provinsi Jawa Timur Sumber: Data diolah

Gambar 3 menjelaskan sebaran status kinerja pembangunan wilayah (agregat) masing-masing kabupaten/kota berdasarkan keempat dimensi. Secara keseluruhan kabupaten/kota di Provinsi Jawa Timur, menurut kinerja pembangunan wilayah agregat terdapat 6 kabupaten kota yang memiliki kinerja tinggi; 20 kabupaten/kota dengan kinerja sedang; dan 12 kabupaten berkinerja rendah. Secara spasial, pola wilayah berkinerja tinggi terpusat pada kawasan Kota Surabaya dan periferinya (Kabupaten Gresik, Sidoharjo, Pasuruan), dan tiga kota yang terpisah (Kota Kediri dan Madiun).

Tingginya kinerja klaster Wilayah Pantura didukung oleh faktor tingginya pendapatan wilayah dan rumah sehat serta kemiskinan dan penduduk dengan gangguan kesehatan yang rendah. Keberhasilan Kota Kediri didukung oleh capaian kriminalitas yang rendah serta pendapatan wilayah dan partisipasi sekolah yang tinggi. Kinerja pembangunan 
Kota Madiun yang tinggi disebabkan oleh tingginya fasilitas kesehatan dan penduduk lulusan pendidikan tinggi.

Wilayah berkinerja rendah terpusat di Wilayah Tapal Kuda (kecuali Kota dan Kabupaten Probolinggo). Wilayah Tapal Kuda merupakan wilayah dengan rata-rata kinerja terrendah (0.287). Lima dari tujuh anggotanya memiliki kinerja terkategori rendah, yakni Kabupaten Lumajang, Jember, Banyuwangi, Bondowoso, dan Situbondo.

Rendahnya kinerja Wilayah Tapal Kuda disebebakan oleh masih lemahnya kinerja dimensi pendidikan dan kesehatan masyarakat. Beberapa kabupaten di Wilayah Tapal Kuda merupakan wilayah dengan kasus gizi buruk dan persen penduduk dengan keluhan dan gangguan kesehatan mengganggu keseharian yang tinggi serta tingkat rata-rata lama sekolah, angka partisipasi sekolah, dan persen rumah sehat yang rendah.

Madura bagian barat (Kabupaten Bangkalan dan Sampang), dan Wilayah Tengah bagian barat (Kabupaten Ngawi, Ponorogo, dan Magetan), sedangkan Kabupaten Tuban, Jombang, dan Blitar cenderung acak (tidak berkelompok).

Pada Kabupaten Bangkalan dan Sampang, kinerja pembangunan rendah dipengaruhi oleh persen penduduk miskin yang sangat tinggi dan rendahnya angka partisipasi sekolah. Selain hal tersebut, faktor lain yang membuat kinerja pembangunan wilayah Kabupaten Sampang lemah adalah pendapatan wilayah, tingkat fasilitas kesehatan, dan tingkat pendidikan masyarakat terendah, serta persen penduduk dengan keluhan dan gangguan kesehatan mengganggu keseharian yang tertinggi. Sedangkan lemahnya kinerja Kabupaten Bangkalan dikarenakan faktor partisipasi sekolah dan penduduk dengan lulusan pendidikan tinggi yang berada di posisi paling rendah.

Pada Wilayah Tengah, terdapat Kabupaten Magetan dan Ponorogo yang merupakan klaster berkinerja pembangunan wilayah rendah. Kinerja pembangunan wilayah ini dipengaruhi oleh faktor pendapatan wilayah yang rendah, serta persen pengangguran dan kasus gizi buruk yang relatif tinggi.

Pada Wilayah Pantura, Wilayah dengan kinerja pembangunan rendah berada pada Kabupaten Tuban yang akibatkan lemahnya kinerja dimensi sosek, pendidikan, dan kesehatan. Kabupaten Tuban yang memiliki kinerja pembangunan terendah di Jawa Timur dipengaruhi oleh tingginya persen penduduk miskin, angka kasus kriminal, kasus gizi buruk; serta rendahnya kontribusi sektor industri manufaktur, persen rumah sehat, rasio gurumurid, dan angka partisipasi sekolah. Di Wilayah Pansela, terdapat Kabupaten Blitar yang memiliki kinerja pembangunan rendah yang disebabkan rendahnya seluruh kinerja dimensi pembangunan. Faktor untama yang mempengaruhi rendahnya kinerja pembangunan Kabupaten Blitar, diantaranya kasus tindak kriminal, penduduk dengan gangguan kesehatan, dan waktu tempuh antarwilayah yang tinggi; serta rendahnya rasio tempat tidur rumah sakit, rasio guru-murid, penduduk lulusan pendidikan tinggi, dan rasio jalan per luas wilayah.

\section{Ketimpangan Pembangunan Wilayah}

Perbandingan nilai koefisien variasi (CV) pada Tabel 3 menggambarkan ketimpangan wilayah yang terjadi antarwilayah maupun secara keseluruhan (tingkat provinsi). Nilai masing-masing CV kemudian dilakukan perhitungan pengkategorian status pada Tabel 3, diketahui kriteria penentuan status ketimpangan, sebagai berikut:

a. Ketimpangan Rendah, merupakan ketimpangan yang memiliki nilai $\mathrm{CV}$ kurang dari 0.119 .

b. Ketimpangan Sedang, merupakan ketimpangan yang memiliki nilai $\mathrm{CV}$ diantara 0.119-0.203.

c. Ketimpangan Tinggi, merupakan ketimpangan yang memiliki nilai $\mathrm{CV}$ lebih dari 0.203 .

Secara keseluruhan tingkat ketimpangan wilayah diantara kabupaten/kota di Provinsi Jawa Timur sebesar 0.329, maka nilai CV Jawa 
Timur terkategori tinggi. Hal ini tergambar dari perbedaan rata-rata (geomean) kinerja Wilayah Pantura (0.369) dengan Wilayah Tapal Kuda (0.287). Nilai CV Wilayah Pantura (0.275) merupakan nilai $\mathrm{CV}$ tertinggi yang menandakan tinggi pula tingkat ketimpangan di dalam
Wilayah Pantura. Di lain pihak Wilayah Pansela dan Madura merupakan wilayah dengan kinerja pembangunan yang cenderung homogen (ketimpangan rendah). Wilayah Madura memiliki homogenitas dalam kinerja pembangunan yang rendah.

Tabel 4. Perbandingan koefisien variasi (CV) dan geomean kinerja pembangunan wilayah berdasarkan wilayah geografis

\begin{tabular}{lllllll}
\hline & Pantura & Tengah & Pansela & Tapal Kuda & Madura & Jatim \\
\hline CV Kinerja & 0.275 & 0.198 & 0.098 & 0.117 & 0.038 & 0.241 \\
Geomean Kinerja & 0.397 & 0.341 & 0.303 & 0.287 & 0.290 & 0.329 \\
\hline
\end{tabular}

Ketimpangan yang signifikan juga terjadi pada wilayah Grebangkertosusila (Gresik, Bangkalan, Mojokerto, Surabaya, Sidoharjo, dan Lamongan) yang merupakan kawasan metropolitan dan kawasan satuan wilayah pengembangan. Kehadiran Jembatan Suramadu, belum memberikan kesempatan lebih bagi Bangkalan untuk meningkatkan kinerja pembangunan. Selain itu kondisi demikian juga terjadi pada pola hubungan pusat-periferi antara Kota Blitar (pusat) dengan Kabupaten Blitar (periferi) dan Kota Madiun (pusat) Kabupaten Ponorogo, Magetan, dan Ngawi (periferi). Wilayah pusat memiliki kecenderungan untuk berkinerja lebih tinggi daripada wilayah periferinya.

\section{Pola Spasial Kinerja Pembangunan Wilayah}

Autokolerasi spasial menggambarkan bagaimana aspek spasial dapat mempengaruhi kinerja pembangunan wilayah. Analisis moran I menghasilkan output indeks moran (I) sebesar 0.342. Nilai indeks moran yang tidak sama dengan nol (0) menyatakan bahwa terjadi autokolerasi antarwilayah pada kinerja pembangunan wilayah di Provinsi Jawa Timur, sedangkan nilai dengan nilai $p$-value $(0.00064)$ dan z-score (3.4144) menyatakan pola autokorelasi spasial yang terjadi membentuk pola klaster (berkelompok). Hal senada juga dikemukaan dalam kajian Munibah et al. (2015) dan $\mathrm{Yu} \&$ Wei (2008) bahwa tingkat pembangunan wilayah memiliki nilai autokorelasi spasial yang positif dengan kecenderungan pola bergerombol. Hal ini memperkuat pernyataan bahwa keterkaitan (linkage) merupakan faktor penting dalam pembangunan wilayah. Proses pembangunan tidak lagi bisa menggunakan pendekatan parsial dan sektoral, akan tetapi harus memperhatikan aspek kewilayahan yang menciptakan keberimbangan. Pembangunan wilayah berimbang menjadi penting karena keterkaitan antar wilayah yang bersifat simetris akan mampu mengurangi ketimpangan antarwilayah (Rustiadi et al., 2011).

Jika di lihat lebih mendalam dalam lingkup lokal (kabupaten/kota), output uji LISA dengan menggunakan nilai kinerja pembangunan wilayah 38 kabupaten/kota dan taraf signifikansi $(\alpha)$ sebesar 5 persen, menghasilkan klasifikasi autokolerasi spasial sebagai berikut: Kuadran HH (High-High), LH (Low-High), dan LL (Low-Low). Sebaran klasifikasi autokolerasi spasial tersebut kemudian dipetakan pada Gambar 4. 


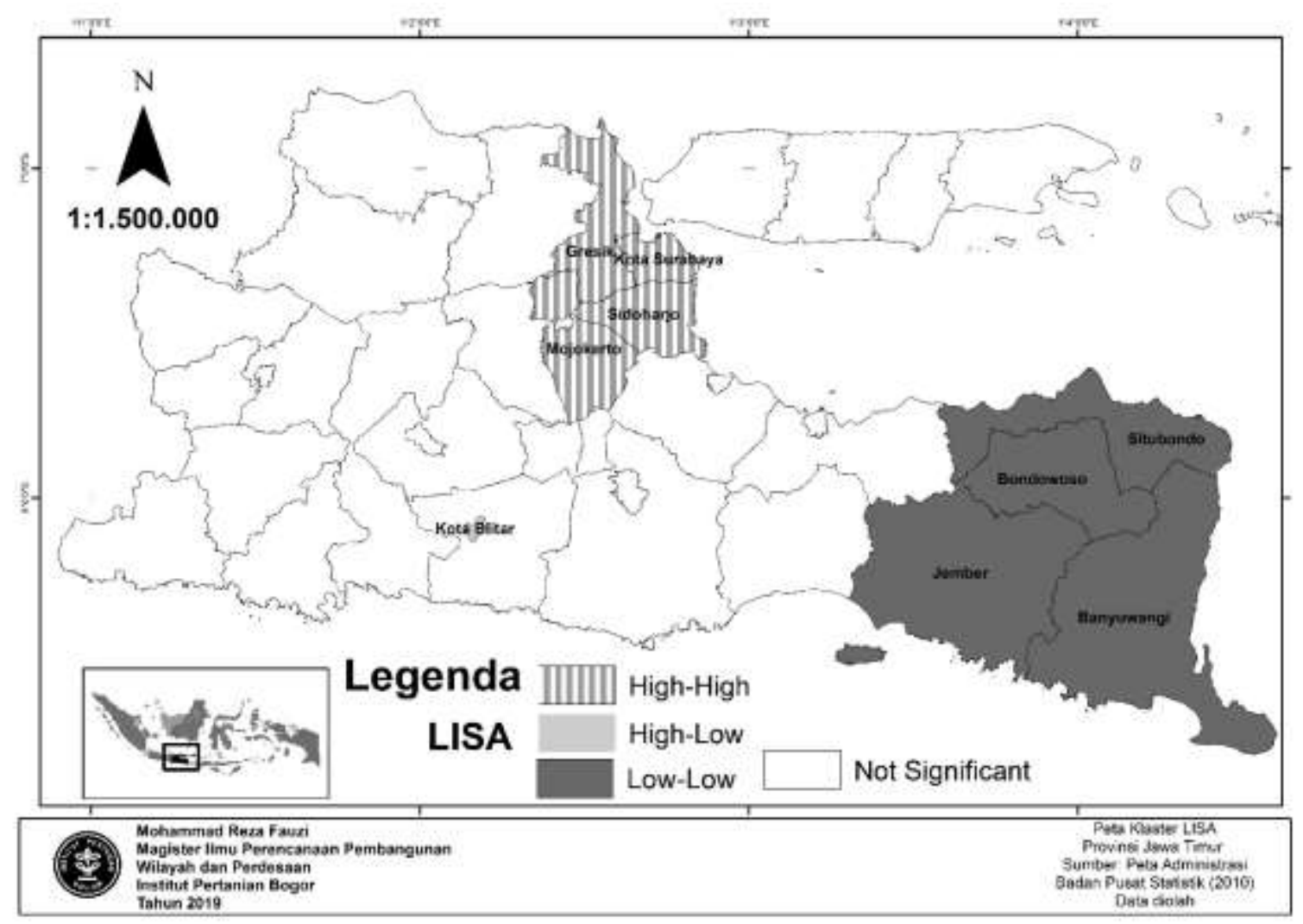

Gambar 4. Peta klaster LISA kinerja pembangunan wilayah di Provinsi Jawa Timur

Kuadran HH (High-High), yang terdiri dari Kota Surabaya, Kabupaten Gresik, Sidoharjo, dan Mojokerto. Wilayah ini merupakan wilayah dengan kinerja pembangunan wilayah relatif tinggi yang dikelilingi wilayah berkinerja tinggi. Kuadran HL (High-Low), yang terdiri dari Kota Blitar. Wilayah ini merupakan wilayah dengan kinerja pembangunan relatif tinggi dengan kinerja pembangunan wilayah tetangga yang rendah. Kuadran LL (Low-Low), yang terdiri dari Kabupaten Situbondo, Bondowoso, Jember dan Banyuwangi. Wilayah ini merupakan wilayah dengan kinerja pembangunan relatif rendah yang dikelilingi wilayah berkinerja rendah pula. Hal ini menunjukan bahwa kinerja pembangunan wilayah kabupaten tersebut memiliki ketergantungan terhadap kinerja pembangunan wilayah tetangganya.

Kota Surabaya, Kabupaten Gresik, dan Sidoharjo yang berkinerja tinggi dengan kuadran $\mathrm{HH}$, wilayah ini dapat dikatakan sebagai wilayah maju dengan pola hubungan positif terhadap wilayah sekitarnya. Hubungan ini tercermin pada capaian pendapatan wilayah.
Kota Surabaya dan Kabupaten Sidoharjo memiliki PDRB perkapita tinggi yang memiliki wilayah tetangga dengan pendapatan yang tinggi juga. Semakin tinggi kinerja pembangunan di wilayah tetangganya, maka semakin baik kinerja pembangunan wilayah di Kabupaten Sidoharjo dan Kota Surabaya.

Pola tersebut terjadi di Surabaya sebagai pusat wilayah metropolitan dengan wilayah sekelilingnya yang merupakan wilayah periferi. Hal ini senada dengan yang disampaikan Anwar (2017) yang mengkaji pola spasial pembangunan manusia menunjukan bahwa klaster hotspot atau $\mathrm{HH}$ memiliki kecenderungan berada di wilayah perkotaan.

Kota Blitar yang memiliki kinerja pembangunan wilayah terkategori sedang dengan kuadran HL, memiliki pola hubungan negatif dengan wilayah tetangganya yang berkinerja rendah, yakni Blitar. Semakin maju kinerja pembangunan Kota Blitar, terdapat risiko terjadinya pengaruh negatif bagi kinerja pembangunan Kabupaten Blitar. Hubungan bertolak belakang tersebut tercermin pada capaian indikator penduduk lulusan pendidikan 
tinggi. Pada indikator tersebut, Kabupaten Blitar berada pada posisi empat terbawah dengan nilai $3.08 \%$, sedangkan Kota Blitar memiliki nilai penduduk lulusan perguruan tinggi $8.94 \%$ dan berada pada posisi 6 tertatas. Maka dapat diindikasikan terjadi hubungan asimetris dan menjadi indikasi adanya fenomena "brain drain". Hal ini harus menjadi perhatian serius agar tidak menimbulkan beban dan kerugian yang berkelanjutan.

Kondisi Kabupaten Situbondo, Bondowoso, Jember, dan Banyuwangi yang memiliki kinerja rendah dengan kuadran LL. Kondisi tersebut diartikan tingkat kinerja wilayah tetangga, yakni Kabupaten Lumajang, Probolinggo, dan Situbondo, sangat signifikan mempengaruhi baik-buruknya kinerja pembangunan tersebut. Pola hubungan ini terindikasi melalui kualitas pendidikan masyarakat. Indikator rata-rata lama sekolah (RLS) Kabupaten Bondowoso (7.1 tahun), Jember (6.2 tahun), dan Banyuwangi (6 tahun), dipengaruhi RLS Kabupaten Situbondo (5.5 tahun), Probolinggo (6 tahun), dan Lumajang (7.2 tahun).

\section{KESIMPULAN DAN SARAN}

Kinerja pembangunan wilayah di Provinsi Jawa Timur berdasarkan dimensi sosial ekonomi, akses dan kualitas pendidikan dan kesehatan masyarakat, serta aksesibilitas wilayah sangat bervariatif. Terdapat enam kabupaten/kota berkinerja tinggi, delapan belas kabupaten/kota berkinerja sedang dan tiga belas kabupaten/kota berkinerja rendah.

Kabupaten/kota di Wilayah Pantura secara umum memiliki kinerja pembangunan wilayah yang lebih baik, jika dibandingkan dengan Wilayah Tengah, Pansela, Tapal Kuda dan Madura. Ketimpangan pembangunan wilayah tertinggi di Provinsi Jawa Timur tergolong tinggi. Pada lingkup wilayah, ketimpangan tertinggi terjadi di Wilayah, sedangkan nilai $\mathrm{CV}$ terendah berada pada Wilayah Madura. Kinerja pembangunan wilayah di Provinsi Jawa Timur dipengaruhi oleh aspek spasial dan kedekatan wilayah (autokorelasi spasial) secara signifikan dengan kecenderungan membentuk sebuah klaster (berkelompok).

Kebijakan pembangunan wilayah di Provinsi Jawa Timur sudah sepatutnya dilakukan dengan pendekatan berbeda dan memperhatikan aspek keterkaitan wilayah (regional linkages), yang terbukti dari nilai autokorelasi spasial dan terciptanya klaster kinerja pembangunan berdasarkan kedekatan spasial.

Pada contoh kasus Kabupaten Situbondo, Bondowoso, Jember dan Banyuwangi, kebijakan pembangunan tidak bisa diformulasikan secara parsial, tetapi harus terintegrasi dengan kebijakan di wilayah sekitarnya yakni Kabupaten Lumajang, Probolinggo, dan Kota Probolinggo yang mempengaruhi secara signifikan kinerja pembangunan wilayah tersebut.

Wilayah Tapal Kuda yang menjadi pusat wilayah dengan kinerja pembangunan rendah memerlukan perbaikan kebijakan dalam memperbaiki kualitas pendidikan dan kesehatan masyarakat serta aksesibilitas wilayah. Peningkatan kinerja pendidikan dan kesehatan dapat dilakukan dengan meningkatkan akses dan partisipasi sekolah, meningkatkan fasilitas dan pelayanan kesehatan, serta menurunkan kasus gizi buruk. Pada Kabupaten Blitar di Wilayah Pasela memerlukan peningkatan kinerja pada dimensi sosial ekonomi, pendidikan kesehatan dan aksesibilitas wilayah. Permasalahan aksesibilitas wilayah di Wilayah Pansela dan Tapal Kuda diharapkan dapat teratasi melalui pembangunan Jalan Lintas Selatan (JLS). Pembangunan JLS akan menghubungkan pesisir Kabupaten Pacitan, Trenggalek, Tulungagung, Blitar Malang Lumajang, Jember, hingga Banyuwangi diharapkan akan memperbaiki aksesibilitas dan ketersediaan jalan di Wilayah Pansela. Upaya ini diharapkan dapat membagi konsentrasi industri di Wilayah Pantura dan merangsang pengembangan potensi lokal. Sehingga dapat berdampak pada perbaikan perekonomian, akses dan kualitas pendidikan dan kesehatan masyarakat. 


\section{DAFTAR PUSTAKA}

Anwar, A. (2017). Ketimpangan Spasial Pembangunan Ekonomi dan Modal Manusia di Pulau Jawa: Pendekatan Explatory Spatial Data Analysis. Asian Journal of Innovation and Entrepreneurship, 2 (2), 90-109.

BPS Jatim. (2018). Provinsi Jawa Timur dalam Angka 2018. BPS Provinsi Jawa Timur.

Brotodewo, N. (2010). Penilaian Indikator Transportasi Berkelanjutan pada Kawasan Metropolitan di Indonesia. Jurnal Perencanaan Wilayah dan Kota, 21 (3), 165-182.

Cobbinah, P. B., \& Black, R. (2011). Reflections on Six Decades of The Concept of Development: Evaluation and Future. Journal of Sustainable Development in Africa, 13 (7), 143-158.

Dai, X., \& Zhang, J. (2011). The TOPSIS Analysis on Regional Disparity of Economic Development in Zhejiang Province. Canadian Social Science, 7 (5), 135-139.

Dhiyaa'ulhaq, M. (2017). Analisis Penyebaran Kemiskinan dan Pengaruh Industri Mikro dan Kecil terhadap Kemiskinan di Daerah Istimewa Yogyakarta. Institut Pertanian Bogor.

Ezkirianto, R. (2013). Analisis Keterkaitan Antara Indeks Pembangunan Manusia dan PDRB Perkapita di Indonesia (Periode Tahun 2006-2011). Institut Pertanian Bogor.

Griffith, D., \& Chun, Y. (2013). Spatial Autocorrelation and Spatial Filtering. Handbook of Regional Science, M. M. Fischer \& P. Nijkamp Ed., 1477-1507. Berlin Heidelberg: Springer Reference.

Harmes, Juanda, B., Rustiadi, E., \& Barus, B. (2017). Pemetaan Efek Spasial pada Data Kemiskinan Kota Bengkulu. Journal of Regional and Rural Development Planning, 1 (2), 192-201.
Indrashanty, A., \& Legowo, P. S. (2016). Aksesibilitas dan Mobilitas Transportasi di Provinsi Bengkulu dalam Konteks Negara Maritim dan Penguatan Daerah Tertinggal. Jurnal Penelitian Transportasi Multimoda, 14 (2), 95-104.

Kansky, K., \& Danscoine, P. (1989). Measures of Network Structure. Flux, Special, 89121.

Krimi, M. S., Yusop, Z., \& Hook, L. S. (2010). Regional Development Disparities in Malaysia. Journal of American Science, 6 (3), 70-78.

Lee, J., \& Wong, D. W. S. (2001). Statistical Analysis with Arcview GIS. John Wiley $\&$ Sons, Inc.

Lumbatoruan, E. P., \& Hidayat, P. (2013). Analisis Pertumbuhan Ekonomi dan Indeks Pembangunan Manusia (IPM) Provinsi di Indonesia. Jurnal Ekonomi dan Keuangan, 2 (2), 14-27.

Mahi, A. K. (2016). Pengembangan Wilayah: dan Aplikasi Teori (Pertama). Kencana.

Munibah, K., Widiatmaka, \& Widjaja, H. (2015). Spatial Distribution of Regional Development Level Using Spatial Autocorrelation Approach (a Case Study: Cianjur Regency, West Java). The 1st International Conference of Indonesian Society for Remote Sensing, 158-164. Surabaya: Geomatic Engineering, Institut Teknologi Sepuluh Nopember (ITS) Surabaya.

Panjaitan, W. M. (2012). Penerapan Regresi Spasial pada Pemodelan Kasus Ketergantungan Spasial (Studi Kasus: Indeks Pembangunan Manusia di Indonesia Tahun 2010). Institut Pertanian Bogor.

Pratiwi, M. C. Y., \& Kuncoro, M. (2016). Analisis Pusat Pertumbuhan dan Autokorelasi Spasial di Kalimantan. Jurnal Ekonomi dan Pembangunan Indonesia, 16 (2), 81-104. 
Putra, F. S. (2017). Analisis Spasial Produk Domestik Regional Bruto Tengah, Kabupaten/Kota di Provinsi Jawa. Universitas Islam Indonesia.

RPJMD Jatim. (2014). Rencana Pembangunan Jangka Menengah Daerah Provinsi Jawa Timur tahun 2014-2019. Pemerintah Provinsi Surabaya.

Rustiadi, E., Saefulhakim, S., \& Panuju, D. R. (2011). Perencanaan dan Pengembangan Wilayah. Crestpent Press dan Yayasan Obor.

Salonen, M. (2014). Analysing Spatial Accessibility Patterns with Travel Time and Distance Measures: Novel Approaches for Rural and Urban Contexts. University of Helsinki.

Sulistyono, D., Mawardi, A. F., \& Widjanarko. (2018). Penentuan Prioritas Pembangunan Infrastruktur Jalan Wilayah Kabupaten/Kota di Provinsi Jawa Timur yang Mempunyai Aksesibilitas Rendah. Seminar Nasional Perubahan Teknologi Sosial 3. UPT PMK Sosial Humaniora. Fakultas Bisnis dan Manajemen. Institut Teknologi Sepuluh Nopember.

Todaro, M. P., \& Smith, S. C. (2011). Pembangunan Ekonomi. Erlangga.

Tzeng, G.-H., \& Huang, J.-J. (2011). Multiple Attribute Desition Making: Methods and Application. CRC Press.

UNDP. (1990). Human Development Report. New York.

Yu, D., \& Wei, Y. D. (2008). Spatial Data Analysis of Regional Development in Greater Beijing, China, in A GIS Environment. Regional Science, 87 (1), 97-117. 